\title{
The Simultaneous Human FVIII/vWF Purification and Virus Inactivation Combined in Chromatographic Column
}

\author{
Sergiy P Havryliuk', levgenia M Krasnobryzha², Olena S Havryliuk ${ }^{3,4}$ and Georgii L Volkov ${ }^{3,4 *}$ \\ ${ }^{1}$ Department of SPC "Interpharmbiotech", Head of Chromatography Purification TOV, 03680 Kyiv, Ukraine \\ ${ }^{2}$ Project Manager of Covance Clinical and Periapproval Services LLC, 03038 Kyiv, Ukraine \\ ${ }^{3}$ Scientific consultant of Neutromics Ukraina TOV, Kiyv, Ukraine \\ ${ }^{4}$ Department of "Shijir International" LLC Head of QC, Ulaanbaatar/Raining Valley, Mongolia
}

\begin{abstract}
Well known that the decrease of the number of degrees of freedom prevents protein's denaturation. In the previous investigation, we showed that the chromatographic gel binding protein can serves as an agent reducing the number of degrees of freedom of the protein. In addition, the high dynamic capacity of new developed gels provided a satisfactory retention of the peptide/protein at elevated temperature of the chromatographic process. These both factors allowed the implement of the virus inactivation for the peptide (streptokinase fragment SK1-61) and low (milk lysozyme) and an average (Fibrinogenolytic enzyme from the snake venom) molecular weight protein directly in the column during targets isolation. The goal of this study was an investigation of the possibility to save the activity of the high molecular weight complex FVIII/vWF, bound by ion exchange and affinity gels during the virus inactivation directly in the chromatographic column. Another goal was to show that the binding protein adsorbent can serves as reliable "sieve" for mechanical washing away of infecting viruses.

Using various chromatographic, photometric, RT-PCR approaches it was discovered that the high dynamic capacity, which determines the high temperature-depending capacity of the adsorbent, allowed to perform the virus-inactivating complex FVIII/VWF by solvent/detergent treatment directly in the chromatographic column at the temperature $40-50^{\circ} \mathrm{C}$ during a long time $3-5 \mathrm{hrs}$. The FVIII biological activity was completely preserved; enveloped and non-enveloped viruses were effectively removed. The level of modeling virus elimination was sufficient for a full inactivation of viruses that allowed us to recommend this method to use in pharmaceutical industry.
\end{abstract}

Keywords: FVIII/Vwf complex; Virus inactivation; Virus titer; RTPCR; Chromatography

Abbreviations: FVIII/vWF: Complex of Factor VIII and von Willebrand Factor; MW: Molecular Weight; NDF: Number of Degree of Freedom; S/D: Solvent/Detergent; LEV/LEVs: Virus (es) Enveloped by Lipid Membrane; NLEV/NLEVs: Non-enveloped Virus (es); IFA method: Method of Immune-fermental Analysis; FITC: Fluorescein Isothiocyanate; RT-PCR method: Real-time PCR Method; $\mathrm{TCID}_{50}$ 50\% Tissue Culture Infectious Dose; DBC: Dynamic Binding Capacity; T-DBC: Temperature-depending Binding Capacity; SEC: Size Exclusion Chromatography; IEC: Ion Exchange Chromatography; RPC: Reverse Phase Chromatography; HPLC: High Performance Liquid Chromatography; GC: Gas Chromatography; FID detector: Flame Ionization Detector; UV-detector: Ultra Violet Detector

\section{Introduction}

Treatment with Solvent/Detergent (S/D) is a widely used method for ensuring the virus safety of human VIII/vWF concentrate. This method includes following S/D combinations: tri- $n$-butyl (TnBP) or di-n-propyl (DnPP) phosphates, or octoxynol and polysorbates (Tweens) $20 / 80$ or Tritons (X-45 or X-100) or sodium cholate/ desoxycholate [1-8]. The S/D concentration was the most critical parameter, typically $0.3 \%$ solvent and $1 \%$ detergent, most frequently $1 \%$ [6], less often $0.3 \%$ and $0.2 \%$, respectively $[7,8]$. A concentration as low as $0.15 \% \mathrm{TnBP} / 0.5 \%$ Triton $\mathrm{X}-100$ was still completely effective, but an extended incubation period was required [3]. The incubation time was depending from virus type, $\mathrm{R} / \mathrm{D}$ concentration and detergent nature and can continue from 2-5 $\min [9]$ to 6-24 hrs [9,10] to achieve a satisfied virus reduction. Normally the temperature of the treatment process was limited by the fast FVIII denaturation and did not exceed 30 [2-5], less often $2-8[1,3,10]$ or $37^{\circ} \mathrm{C}[6-10]$.
The inactivation of most enveloped viruses (LEVs) was rapid, i.e., $>5.0 \log _{10}$ in $2 \mathrm{~min}$, although the inactivation of vaccinia virus was slower, i.e. $4.0 \log _{10}$ in $1 \mathrm{hr}$ in case of using TnBP/Triton X-100. Virus inactivation with TnBP/Tween 80 was slower, but effective inactivation of most LEVs was achieved ( 4.1 to $>6.3 \log _{10}$ ) within $30 \mathrm{~min}$. To achieve a $4.0 \log _{10}$ reduction of vaccinia required an incubation time of $10 \mathrm{~min}$ with TnBP/Triton X-100 and 6-24 hrs with TnBP/Tween 80 [10].

It is important to note two significant weaknesses of the $S / D$ treatment. First, it does not inactivate Non-Enveloped Viruses (NLEVs) [11] and it is necessary for further NLEVs reduction to use wet/dry heat treatment at $60-100^{\circ} \mathrm{C}[12-14]$, or nanofiltration $[15,16]$, or UV-/gamma irradiation [17]. Second, the incubation of a highmolecular weight (so labile [18]) protein at $37^{\circ} \mathrm{C}$ and exposure to S/D causes its denaturation; additional losses of the denatured target product are added by filtration, removing R/D and NLEVs, due to the high turbulence of the pumped protein solution [19].

In the previous investigation, we showed that the chromatographic gel binding protein can serves as an agent reducing the number

${ }^{*}$ Corresponding author: Georgii L Volkov, Scientific Consultant of Neutromics Ukraina TOV, 12, Melnikova Street, 04050 Kyiv, Ukraine, Tel: +380 503306478 , +380 44 4268342; E-mail: volkov.georgii@neutromics.com.ua

Received March 25, 2017; Accepted April 29, 2017; Published August 14, 2017

Citation: Havryliuk SP, Krasnobryzha IM, Havryliuk OS, Volkov GL (2017) The Simultaneous Human FVIII/vWF Purification and Virus Inactivation Combined in Chromatographic Column. J Biomol Res Ther 6: 157. doi:10.4172/21677956.1000157

Copyright: (C) 2017 Havryliuk SP, et al. This is an open-access article distributed under the terms of the Creative Commons Attribution License, which permits unrestricted use, distribution, and reproduction in any medium, provided the original author and source are credited. 
Citation: Havryliuk SP, Krasnobryzha IM, Havryliuk OS, Volkov GL (2017) The Simultaneous Human FVIII/vWF Purification and Virus Inactivation Combined in Chromatographic Column. J Biomol Res Ther 6: 157. doi:10.4172/2167-7956.1000157

Page 2 of 9

of degrees of freedom of the protein. In addition, the high dynamic capacity of new developed gels provided a satisfactory retention of the peptide/protein at elevated temperature of the chromatographic process [20]. These both factors allowed the implement of the virus inactivation for the peptide (streptokinase fragment $\mathrm{SK}^{1-61}$ ) and low (milk lysozyme) and an average (fibrinogenolytic enzyme from the snake venom) molecular weight proteins directly in the column during targets isolation. The S/D treated peptide/protein directly in the chromatographic column at the temperature $30-45^{\circ} \mathrm{C}$ during $3-6 \mathrm{hrs}$ completely preserved their biological activity [20].

On the other hand, it's well known that any chromatography purification step leads to the reduction of virus contamination not less than 0.5-3.0 $\log _{10}$ per step [17,21]. This phenomenon can be explained by the fact that the chromatographic adsorbent, while firmly retaining the target protein, allowed washing out unrelated or weakly bound viruses, demonstrating a "filtering" model. It was confirmed in our previously published paper, where was shown that the target proteins, bound on the chromatographic gel, were effectively washed out from model NLEVs (CPV and BEV) to 8.30-9.51 $\log _{10}$ [20].

Described above protective and "filtering" effects of chromatographic matrix led us to the idea to combine the purification process of the complex FVIII/vWF with its simultaneous virus inactivation directly in the chromatographic column, which would ensure at least to advantages namely: a) The reduction of activity loss under the denaturation; and b) The LEVs destruction and NLEVs washing out. The development of such virus reduction process for the human FVIII/vWF concentrate is presented in this paper.

\section{Materials and Methods}

\section{Target protein}

The target protein-complex FVIII/vWF-was manufactured by early described technology from human blood plasma [22]. The proteins quantity were measured by the standard methods with Human Factor VIII total antigen ELISA kit and Human vWF ELISA kit (Innovative Research, Novi, USA) and chromogenic kits from Chromogenix AB (Möldland, Sweden). The FVIII coagulation activity was measured by the FVIII:C kit (Technoclone GmbH, Vienna, Austria). The total protein in the collected samples was determined by Bradford method [23] with Stoscheck modification [24].

\section{Virus models}

All viruses were obtained from the American Type Culture Collection (ATCC). Corresponded cell lines for virus titration were received from ATCC too.

Bovine viral diarrhea virus (BVDV): Pestivirus, VR-534, strain NADL, an enveloped virus, ssRNA, $40-50 \mathrm{~nm}$, served as a model for Hepatitis $C$ virus.

Canine parvovirus (CPV): Parvovirus, feline panleukopenia virus (VR-2016, Cornell-780916-115), a non-enveloped virus, ssDNA, 18-26 $\mathrm{nm}$, served as a model for Parvovirus B19.

Bovine enterovirus type 3 (BEV): Picornavirus, enterovirus, (VR755 , PS 89), a nonenveloped virus, ssRNA, $22-30 \mathrm{~nm}$, served as a model for Hepatitis A virus.

Duck Hepatitis B Virus type 1 (DHBV): Picornavirus, enterovirus, (VR-1313, DLR-62), an enveloped, dsDNA, 30-40 nm, served as a model for Hepatitis B virus.
Murineleukemiavirustype $C(M u L V)$ : Retroviridae,gammaretrovirus, (VR-884, 292A), an enveloped, ssRNA, 80-110 nm, served as a model for Human immunodeficiency virus and Human T-lymphotropic virus.

Pseudorabies suid herpes virus 1 (PRV): Herpesviridae, varicellovirus, (VR-2106, S62/26), an enveloped, dsDNA, 40-50 nm, served as a model for Herpes virus.

\section{Virus titration}

Untreated and S/D treated at different conditions samples were virus infected and tested. Virus titers were determined by endpoint titration microtiter plate assay (serial dilutions, five parallel samples per dilution), examining ATCC-recommended cell lines for virus-induced changes in morphology (cytopathic effect, syncytia formation). Titers were calculated using the method of Kaerber [25] and Spearman [26] and were expressed as $\log 50 \%$ tissue culture infectious dose $\left(\mathrm{TCID}_{50}\right)$ $[25,26]$. Alternatively, if no virus was detected, a theoretical minimum detectable level (mdl) was calculated according to the formula:

$$
\operatorname{mdl}=\frac{-\ln 0,0183}{\text { tested volume }}
$$

This corresponds to a Poisson distribution with a $95 \%$ confidence limit.

\section{Quantitative real-time PCR}

For extraction and purification viral RNA/DNA from the protein samples "QIAamp Viral RNA/DNA Mini Kit” from QIAGEN China Co., Shanghai, China was used.

BVDV RNA quantity was determined by Real-time PCR (RTPCR) method with «virotype BVDV RT-PCR Kit», BEV RNA with «artus Enterovirus LC RT-PCR Kit RUO» (both kits from QIAGEN China Co., Ltd., China, Shanghai) with forward/reverse primers shown by Uruno et al. [27] and Ley et al. [28], respectively. For quantitative DHBV DNA were used primers according Zubkova et al. [29] and Wang et al. [30], for CPV DNA-Sharma et al. [31] and Kapil et al. [32], for PRV DNA-Tombacz et al. [33], for MuLV RNA-Lin et al. [34] with «QuantiFast Pathogen+IC Kit». Quantitative Real-time PCR was performed on the Rotor-Gene Q 2plex HRM System instrument (QIAGEN China Co., Ltd., China, Shanghai). The data was expressed as $\log _{10}$ of ratio between virus DNA/RNA detected in infected protein sample before and after purification and designated in the manuscript as parameter $\mathrm{t}_{\mathrm{T}^{\circ} \mathrm{C}}$ (example $\left.\mathrm{t}_{45}=4.15\right)$

\section{Solvent/Detergent treatment directly in chromatographic process and virus elimination level calculation}

S/D treatment of complex FVIII/vWF was performed according to scheme shown on the Figure 1. For the S/D treatment of target protein one of the last steps of chromatographic purification before SEC polishing operation was chosen.

The model virus spike into the protein sample dissolved in the equilibration buffer to the final protein concentration $2.5 \mathrm{mg} / \mathrm{mL}$ was performed to achieve the following final virus amount in the sample: BVDV-1.8 $\times 10^{8}, \mathrm{CPV}-3.2 \times 10^{9}, \mathrm{BEV}-1.1 \times 10^{9}, \mathrm{DHBV}-8.4 \times 10^{8}$ MuLV-4.7 $\times 10^{8}$, PRV-2.1 $\times 10^{9}$ total TCID $_{50}$ units in 1.0 column volume $(\mathrm{Vc})$. The protein-virus mixture was incubated for 10-15 min with gentle agitation.

Then the protein sample $(1 \mathrm{Vc})$ infected with model virus was applied on chromatographic column (shown as "XK" on Figure 1, washed by $5-10 \mathrm{Vc}$ and virus concentration (according to titer or 
Citation: Havryliuk SP, Krasnobryzha IM, Havryliuk OS, Volkov GL (2017) The Simultaneous Human FVIII/vWF Purification and Virus Inactivation Combined in Chromatographic Column. J Biomol Res Ther 6: 157. doi:10.4172/2167-7956.1000157

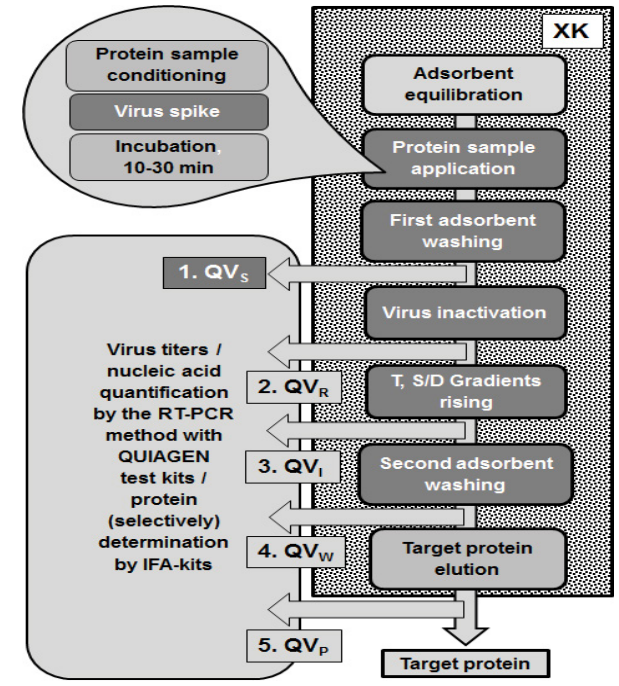

Figure 1: The scheme of experiments on Solvent/Detergent treatment directly in chromatographic process. Chromatographic column is shown as "XK". Virus titer, nucleic acid or virus protein quantity were determined at each of 1, 2, 3, 4 and 5 designated stages, other symbols are described in section "Materials and Methods".

nucleic acid quantity) in the total collected volume was determined. The difference between virus level in protein sample before application to the column and virus level in the washed volume was defined as a start virus level in the infected protein $\mathrm{QV}_{\mathrm{s}}$. After that the target protein bound to adsorbent was subjected to S/D treatment, washed and eluted from the column with subsequent virus determination in each fraction: preparing to inactivation-temperature and $S / D$ gradients rising $\left(\mathrm{QV}_{\mathrm{R}}\right)$, inactivation $\left(\mathrm{QV}_{\mathrm{I}}\right)$, washing $\left(\mathrm{QV}_{\mathrm{W}}\right)$, protein elution $\left(\mathrm{QV}_{\mathrm{P}}\right)$ both by titer and nucleic acid quantity (Figure 1 ).

The factor of virus concentration decrease (FVD) that reflects virus inactivation level was calculated as $\log _{10}$ ratio of virus level detected at any stage of process $\left(\mathrm{QV}_{\mathrm{R}}, \mathrm{QV}_{\mathrm{I}}, \mathrm{QV}_{\mathrm{W}} \mathrm{i} \mathrm{QV}_{\mathrm{P}}\right)$ to the start virus level $\left(\mathrm{QV}_{\mathrm{S}}\right)$.

The infected complex FVIII/vWF was applied on C 10/20 column (GE Helthcare AB, Uppsala, Sweden) packed with $10 \mathrm{ml}$ of chromatographic gels. In the first case it was IEC gel WorkBeads 40S (Bio-Works Technologies AB, Uppsala, Sweden) on the bed height $10 \mathrm{~cm}$ equilibrated with $0.01 \mathrm{M} \mathrm{Na}_{3}$-citrate buffer, $\mathrm{pH} 7.2$, including $0.0026 \mathrm{M} \mathrm{CaCl}_{2}$

The common conditions of direct S/D treatment during the chromatographic process for the protein/virus preparation were the following:

1. The infected target proteins complex application: $1 \mathrm{Vc}$ (final concentration $2.5 \mathrm{mg} / \mathrm{mL}$ ) with flow rate $0.025 \mathrm{Vc} \times \mathrm{min}^{-1}$.

2. The first column washing: $30 \mathrm{Vc}$ with flow rate $0.5 \mathrm{Vc} \times \mathrm{min}^{-1}$ to complete absence of virus material in eluate.

3. The raising of $\mathbf{S} / \mathbf{D}$ inactivation buffer gradient: $10 \mathrm{Vc}$ inactivation buffer with flow rate $0.5 \mathrm{Vc} \times \mathrm{min}^{-1}$ was automatically created by programming linear increasing concentration from 0 to $100 \%$ and applied on the column. The final inactivation buffer included following $\mathrm{R} / \mathrm{D}$ combinations: a) $0.35 \% / 1.0 \% \mathrm{TnBP} / \mathrm{Triton} \mathrm{X}-100$, b) $0.35 \% / 2.0 \% \mathrm{TnBP} /$ Triton $\mathrm{X}-100$, c) $1.05 \% / 1.0 \%$ TnBP/Triton X-100, d) $0.35 \% / 1.0 \%$ TnBP/Twin 80 , e) $0.35 \% / 1.0 \%$ DnPP/Triton X-100.
4. The raising inactivation temperature gradient: on the beginning of inactivation process for inactivation buffer and column thermostabilized gradient was started from 18 to 25 , 35 and $45^{\circ} \mathrm{C}$ for IEC gel during $20 \mathrm{~min}$, therefore a temperature gradient grew in parallel to $\mathrm{S} / \mathrm{D}$ gradient in all cases.

5. The second washing after raising gradient-actual treatment process: column was washed by 30,35 and $40 \mathrm{Vc}$ under 25 , 35 , and $45^{\circ} \mathrm{C}$ with same flow rate $0.5 \mathrm{Vc} \times \mathrm{min}^{-1}$; the column temperature was kept at corresponding buffer temperature.

6. The falling down S/D inactivation buffer and temperature gradients: after the washing the reverse $\mathrm{S} / \mathrm{D}$ and $\mathrm{T}^{\circ}$ gradients were used to reach the initial conditions for $20 \mathrm{~min}$.

7. The third column washing: when the start $\mathrm{T}^{\circ} 18^{\circ} \mathrm{C}$ was reached simultaneously with falling down gradient finishing, the column was washed by $10 \mathrm{Vc}$ equilibration buffer with flow rate $0.5 \mathrm{Vc} \times \mathrm{min}^{-1}$.

8. The target protein elution: the elution was made with flow rate $0.25 \mathrm{Vc} \times \mathrm{min}^{-1}$ by $5 \mathrm{Vc}$ elution buffer: $0.01 \mathrm{M} \mathrm{L}$-histidine buffer, $\mathrm{pH} 7.2$, including $1.5 \%$ mannitol $(\mathrm{w} / \mathrm{w}), 0.013 \mathrm{M}$ Sucrose, $1.0 \mathrm{M} \mathrm{NaCl}$. Under these conditions all model virus material was eluted from the column that means the virus was mainly associated with proteins. After columns sanitization by $0.5 \mathrm{M} \mathrm{NaOH}$ the traces of virus material were detected on gels in very rare cases.

All chromatographic applications were made using ÄKTA explorer system (GE Healthcare AB, Uppsala, Sweden).

\section{S/D Determination in the FVIII/vWF concentrates after Vi- rus inactivation}

The solvent level in final proteins concentrate after S/D treatment was measured by GC method with FID [35], the detergent level-by HPLC with UV-detector (both instruments from E-Chrom Tech, Taiwan) [36].

The adsorbent dynamic binding capacity and temperaturedepending capacity determination

The Dynamic Binding (DBC) and temperature-depending (TDC) capacities of adsorbents were determined on C 10/20 columns (GE Healthcare AB, Uppsala, Sweden) packed with $10 \mathrm{~mL}$ of IEC gel, bed height $10 \mathrm{~cm}$ (packing density factor 1,15-1,20).

DBCs were determined according to standard procedure [37] under chromatographic conditions stipulated above in the chapter "Solvent/Detergent Treatment..."

TDCs were determined by the following way. Target proteins complex was applied on IEC WorkBeads $40 \mathrm{~S}$ gel. The quantity of protein samples was calculated $10 \%$ lower than maximum level of adsorbent $\mathrm{DBC}$ at $20^{\circ} \mathrm{C}$. After sampling and washing the column/buffer temperature were slowly raised on 5 degrees each step and determined the target protein quantity in eluates. 3-5 independent experiments were performed according to chromatographic conditions stipulated above.

\section{Statistical analysis}

The statistical processing of results was carried out by the standard methods [38]. A value of $p<0.05$ was considered statistically significant. Data was presented as a mean \pm Standard Errors (SEM) of at least 5 independent experiments unless otherwise indicated. 
Citation: Havryliuk SP, Krasnobryzha IM, Havryliuk OS, Volkov GL (2017) The Simultaneous Human FVIII/vWF Purification and Virus Inactivation Combined in Chromatographic Column. J Biomol Res Ther 6: 157. doi:10.4172/2167-7956.1000157

\section{Results and Discussion}

In the recent publication we showed [20] that the dynamic capacity of the chromatographic gel determined a possibility of protein virus inactivation directly in a chromatographic process. The effectively of virus elimination was depended from the other parameter of chromatographic gel-a temperature-depending capacity. This parameter characterized the gel ability to retain protein at high temperatures of inactivating buffer. Thus, it was found that the IEC gels (for example, SP and Q Sepharose HP), having a relatively high DBC, exhibited a high TDC, which, however, rapidly decreased at the critical $\left(39-42^{\circ} \mathrm{C}\right)$ temperatures [20] for the proteins retention. Nevertheless, we demonstrated that the above-mentioned IEC gels were able to retain proteins even at a process temperature $45^{\circ} \mathrm{C}$ without denaturation and loss of activity. The RPC gel, on the contrary, almost linearly increased the TDC with raising process temperature [20] due to exposure of additional hydrophobicity on the protein globule surface [39] and creation of new points of the gel-protein interaction.

These results gave us confidence that chromatographic gel WorkBeads $40 \mathrm{~S}$ having high DBC for BSA $\left(>130 \mathrm{mg} \times \mathrm{mL}^{-1}\right)$ at buffer flow 100-500 $\mathrm{cm} \times \mathrm{h}^{-1}$ [40] will have the high TDC for human FVIII/ vWF complex.

\section{TDC and critical zones of FVIII/vWF retention by chromato- graphic gels}

The results of the DBCs comparative study of two well-known IEC gels using for FVIII/vWF complex purification are shown in Figure 2. The WorkBeads $40 \mathrm{~S}$ has a stable maximum of DBC $32.1 \mathrm{mg} \times \mathrm{mL}^{-1}$ at the buffer flow range $100-500 \mathrm{~cm} \times \mathrm{h}^{-1}$. The DBC of SP Sepharose $\mathrm{HP}$, having a stable zone between $100-200 \mathrm{~cm} \times \mathrm{h}^{-1}$, abruptly decreased from 22.5 to 16.2 (28\% drop), 9.3 (57\% drop) and 2.2 (90\% drop) $\mathrm{mg}$ $\times \mathrm{mL}^{-1}$ at the buffer flow rate 250,300 and $350 \mathrm{~cm} \times \mathrm{h}^{-1}$, respectively. These dates help to explain the significant difference between TDCs for FVIII/vWF complex of WorkBeads 40 S and SP Sepharose HP at the range of buffer temperature $20-60^{\circ} \mathrm{C}$ represented in Figure 3 . The TDC of the WorkBeads $40 \mathrm{~S}$ in the range of $30-45^{\circ} \mathrm{C}$ is relatively stable and high $\left(32.1 \mathrm{mg} \times \mathrm{mL}^{-1}\right)$ and shows the tendency to decreasing after $50^{\circ} \mathrm{C}(\sim 8-10 \%$ drop, but this difference is not statistically significant, $p>0.1)$. The FVIII/vWF after action of $45-55^{\circ} \mathrm{C}$ temperature is eluted from column native and its activity was completely saved. Opposite, the early buffer temperature increasing led to dramatic drop in proteins complex dynamic capacity of SP Sepharose HP: from 22.5 to 15.7 ( $>30 \%$ drop) and to 1,1 ( $>95 \%$ drop) $\mathrm{mg} \times \mathrm{mL}^{-1}$ at 30 and $35^{\circ} \mathrm{C}$, respectively (both dates statistically significant compare with previous temperature point, $p_{30}<0.05, p_{35}<0.01$ ). Thus, the process temperature about $20-25$ and $45-50^{\circ} \mathrm{C}$ determines the critical zones of FVIII/vWF retention by SP Sepharose HP and WorkBeads, respectively (Figure 3).

To use a maximal allowed temperature at the FVIII/vWF complex S/D treatment process it's carried out at maximum temperature $45^{\circ} \mathrm{C}$ for WorkBeads 40S.

\section{Virus titer and nucleic acid content}

In general, in all virus inactivation studies the virus titer was a primary parameter and virus titer determination was always followed by infectivity studies. This choice, when it is necessary to determine whether the residual amount of infectious virus, remains reasonable until no suggestion that the new, accurate and adequate methods for this purpose there are more reliable. In fact, due to the destruction of the lipid membrane by the S/D LEV viruses lose the infectious properties and cannot be determined by the Kaerber [25] and Spearman [26]

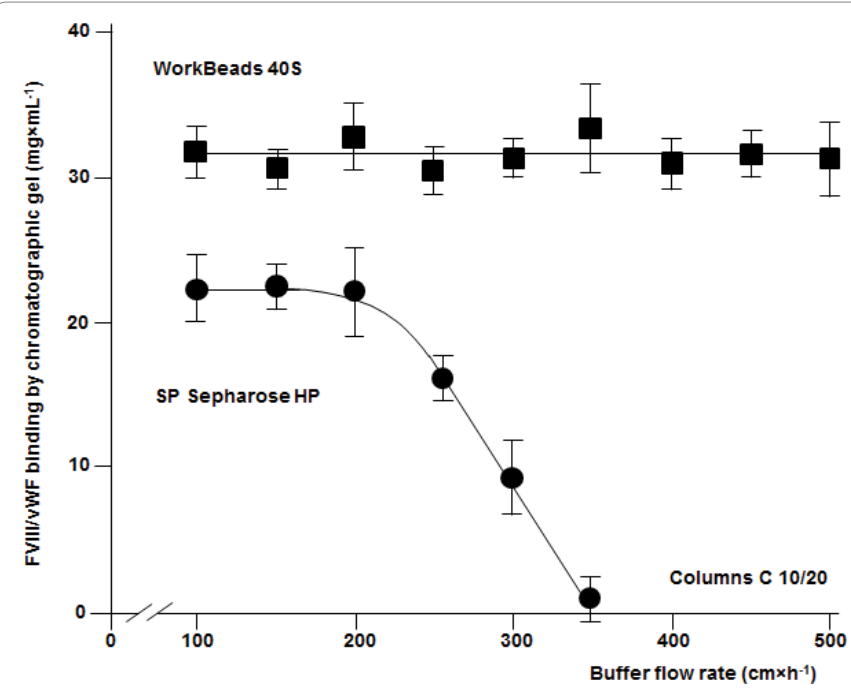

Figure 2: The chromatographic gels dynamic binding capacity determining by capturing human FVIII/VWF depending from the buffer flow rate (all chromatographic conditions are described in the sections "Materials and Methods").

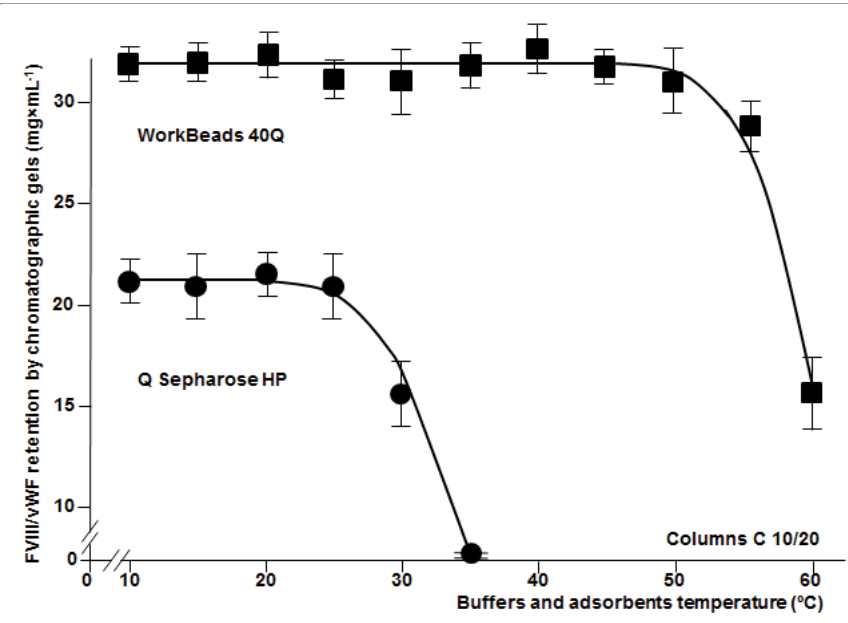

Figure 3: The chromatographic gels temperature-depending dynamic binding capacity determining by the retention of previously captured human FVIII/vWF (all chromatographic conditions are described in the sections "Materials and Methods").

methods. Furthermore, we lost a possibility to calculate the process mass balance [20] using the virus titer.

We received full repetition of previously detected pattern in the present investigations: the method of the virus titer determining gave an adequate result according to FVIII/vWF infectivity in the case of LEV and NLEV models (Tables 1-3). The LEV titer determination didn't leave the hope to calculate process kinetics since the loss in virus infectivity due to the particles destruction and virus proteins denaturation. The virus titration were more acceptable for NLEV infectivity mass balance determination-maximum $24 \%$ of the total infectivity was lost against 4-6\% determined by RT-PCR. Unfortunately, the titration accuracy was very poor again (variants deviation more than $18-22 \%$ in the best cases) and didn't allow definite conclusions.

Quantification of viral nucleic acids by RT-PCR in proteins complex and buffer fractions obtained during inactivation allowed to calculate the process mass balance within $97.0 \pm 2.9 \%$. It means that 
Citation: Havryliuk SP, Krasnobryzha IM, Havryliuk OS, Volkov GL (2017) The Simultaneous Human FVIII/vWF Purification and Virus Inactivation Combined in Chromatographic Column. J Biomol Res Ther 6: 157. doi:10.4172/2167-7956.1000157

instability of the virus nucleic acid (in most experiments not more than $3-4 \%$ of losses, rarely up to $4.1 \%$, Tables 1 allows to calculate the process kinetic to assess what happens to model virus in the process of S/D treatment with small variant's diversity not higher than $8-15 \%$. In contrast, diversity of variants of virus titer of target proteins was more than $16-33 \%$.

Compared with the results of previous publication [20], where we could not accurately detect the ratio of virus particles "leaching" and destruction in the process of inactivation, it was introduced a separate definition of viruses in the steps up to the temperature of inactivation, most inactivation and washing after inactivation.

Therefore, the residual infectivity of treated FVIII/vWF complex was determined by virus titer and virus nucleic acid concentration, but kinetic of treatment process-by virus nucleic acid only.

\section{Direct virus inactivation by S/D treatment during FVIII/vWF purification process by IEC method}

Dependence from process temperature: S/D treatment of FVIII/ vWF complex bound by IEC gel Work Beads 40S was performed on the intermediate stage of protein purification [22] after IEC on WorkBeads 40Q but before SEC-formulation on Superose 12 PG (both gels from GE Healthcare AB, Uppsala, Sweden). The amount of virus retained by proteins complex sample as determined by virus amount in washing material was considered sufficient to proceed with further experiments.

Results of the S/D virus inactivation of FVIII/vWF directly in a chromatographic column depending from process temperature are presented in Table 1 . The S/D buffer temperature plays extremely important role in virus elimination: total levels of LEV decreasing according to PCR-detected virus nucleic acid (calculated from mass- balance) at 25,35 and $45^{\circ} \mathrm{C}$ were $65.7-71.8,89.4-92.6$ and $100 \%$, respectively. Differences between $25-35^{\circ} \mathrm{C}$ were statistically significant for all LEV $\left(p_{\mathrm{DHBV}}<0.001, p_{\mathrm{BVDV}}<0.001, p_{\mathrm{MULV}}<0.001\right.$ and $\left.p_{\mathrm{PRV}}<0.001\right)$. Differences between $25-45^{\circ} \mathrm{C}$ and $35-45^{\circ} \mathrm{C}$ was not sense to calculate because treatment at $45^{\circ} \mathrm{C}$ left a trace amount of viral nucleic acids lower than detection limits of the method. For NLEVs the treatment had the same effect as for LEVs: total elimination was around $80,90 \%$ and $100 \%$ at 25,35 and $45^{\circ} \mathrm{C}$.

Virus nucleic acid analysis of all washes and eluted fractions revealed a proportional dependence of the reduction of all types of viruses from the inactivation buffer temperature, but also an essential qualitative difference between LEVs and NLEVs in virus elimination from chromatographic columns. For example, the MuLV removal rate increased from 1.00 to 1.17 and 1.34 (\% reduction in nucleic acid-NArelated to the stage time in $\mathrm{min}$ ) at 25,35 and $45^{\circ} \mathrm{C}$. Also $\mathrm{CPV}$ removal rate at the same temperatures at the treatment stage increased from 0.81 to 0.98 and 1.26

However, the different LEVs removal rates on each stage demonstrated that the main events of virus destruction occurred at the stage of the actual treatment. At this stage, the speed is the highest, for example, for DHBV it was 1.13 total NA quantities in \% per min at $35^{\circ} \mathrm{C}$; at grows gradient stage- 0.61 and dropping gradient stage- 0.47 . On the other hand, the removal of NLEV s practically with the same rate at each stage indicated that the main mechanism of elimination was a simple mechanical washing of the viruses from the chromatographic column. For example, the values of BEV rate elimination at $35^{\circ} \mathrm{C}$ were $0.87,0.97$ and 0.93 at gradient growth, dropping and treatment, respectively. It cannot be ruled out that along with the basic mechanism of virus destruction in the LEVs inactivation process the washing out mechanism took place.

\begin{tabular}{|c|c|c|c|c|c|c|c|}
\hline \multirow{2}{*}{ S/D treatment stage } & \multirow{2}{*}{$\begin{array}{c}\text { Virus } \\
\text { determination }\end{array}$} & \multicolumn{6}{|c|}{ Decreasing the factor of virus concentration $(F V D)$ as a $\log _{10}(M \pm S E M, n=5)$} \\
\hline & & BVDV & DHBV & MuLV & PRV & CPV & BEV \\
\hline $\begin{array}{l}\text { System growth gradients: } \mathrm{T}^{\circ} 18-25^{\circ} \mathrm{C} .10 \mathrm{Vc} \text { S/D } \\
0-0.35 \% \text { TnBP, } 0-1.0 \% \text { Triton } \mathrm{X}-100\end{array}$ & Nucleic acid & $0.58 \pm 0.04$ & $0.41 \pm 0.03$ & $0.33 \pm 0.02$ & $0.46 \pm 0.04$ & $1.50 \pm 0.11$ & $1.46 \pm 0.17$ \\
\hline $\begin{array}{l}\text { S/D treatment with buffer }(30 \mathrm{Vc}): 0.35 \% \mathrm{TnBP} .1 .0 \% \text { Triton } \\
\mathrm{X}-100,25^{\circ} \mathrm{C}\end{array}$ & Nucleic acid & $6.01 \pm 0.42$ & $5.83 \pm 0.49$ & $5.79 \pm 0.55$ & $5.67 \pm 0.51$ & $4.73 \pm 0.38$ & $4.52 \pm 0.53$ \\
\hline $\begin{array}{l}\text { System } \mathrm{T}^{\circ} \& \mathrm{~S} / \mathrm{D} \text { dropping gradient }(10 \mathrm{Vc}) \text { to start conditions } \\
\text { and washing by } 10 \mathrm{Vc} \text { buffer }\end{array}$ & Nucleic acid & $0.39 \pm 0.03$ & $0.26 \pm 0.03$ & $0.28 \pm 0.02$ & $0.30 \pm 0.02$ & $1.41 \pm 0.15$ & $1.37 \pm 0.14$ \\
\hline \multirow{2}{*}{ Target FVIII/vWF complex elution } & Titer & $1.52 \pm 0.27$ & $1.65 \pm 0.30$ & $1.75 \pm 0.41$ & $1.62 \pm 0.33$ & $1.89 \pm 0.40$ & $2.07 \pm 0.56$ \\
\hline & Nucleic acid & $2.74 \pm 0.19$ & $3.11 \pm 0.25$ & $3.19 \pm 0.28$ & $3.35 \pm 0.26$ & $2.08 \pm 0.12$ & $2.33 \pm 0.19$ \\
\hline Whole process summed FVD & Nucleic acid & $9.72 \pm 0.46$ & $9.61 \pm 0.55$ & $9.59 \pm 0.62$ & $9.78 \pm 0.57$ & $9.72 \pm 0.44$ & $9.68 \pm 0.60$ \\
\hline $\begin{array}{l}\text { System growth gradients: } \mathrm{T}^{\circ} 18-35^{\circ} \mathrm{C} .10 \mathrm{Vc} \text { S/D } \\
0-0.35 \% \text { TnBP, } 0-1.0 \% \text { Triton } \mathrm{X}-100\end{array}$ & Nucleic acid & $1.27 \pm 0.19$ & $1.18 \pm 0.13$ & $1.32 \pm 0.21$ & $1.40 \pm 0.11$ & $1.76 \pm 0.17$ & $1.68 \pm 0.09$ \\
\hline $\begin{array}{l}\text { S/D treatment with buffer }(30 \mathrm{Vc}): 0.35 \% \mathrm{TnBP} .1 .0 \% \text { Triton } \\
\mathrm{X}-100,35^{\circ} \mathrm{C}\end{array}$ & Nucleic acid & $6.74 \pm 0.55$ & $6.51 \pm 0.57$ & $6.81 \pm 0.69$ & $6.58 \pm 0.73$ & $5.71 \pm 0.52$ & $5.58 \pm 0.44$ \\
\hline $\begin{array}{l}\text { System } \mathrm{T}^{\circ} \& \mathrm{~S} / \mathrm{D} \text { dropping gradient }(10 \mathrm{Vc}) \text { to start conditions } \\
\text { \& washing by } 10 \mathrm{Vc} \text { buffer }\end{array}$ & Nucleic acid & $0.78 \pm 0.06$ & $0.90 \pm 0.04$ & $0.85 \pm 0.10$ & $0.79 \pm 0.06$ & $1.67 \pm 0.11$ & $1.80 \pm 0.15$ \\
\hline \multirow{2}{*}{ Target FVIII/vWF complex elution } & Titer & $0.39 \pm 0.08$ & $0.21 \pm 0.06$ & $0.34 \pm 0.04$ & $0.47 \pm 0.09$ & $0.50 \pm 0.12$ & $0.51 \pm 0.10$ \\
\hline & Nucleic acid & $0.84 \pm 0.05$ & $1.02 \pm 0.09$ & $0.72 \pm 0.07$ & $0.86 \pm 0.05$ & $0.59 \pm 0.05$ & $0.56 \pm 0.06$ \\
\hline Whole process summed FVD & Nucleic acid & $9.68 \pm 0.59$ & $9.61 \pm 0.50$ & $9.70 \pm 0.73$ & $9.63 \pm 0.74$ & $9.73 \pm 0.55$ & $9.62 \pm 0.74$ \\
\hline $\begin{array}{l}\text { System growth gradients: } \mathrm{T}^{\circ} 18-45^{\circ} \mathrm{C} .10 \mathrm{Vc} \text { S/D } \\
0-0.35 \% \text { TnBP, } 0-1.0 \% \text { Triton } \mathrm{X}-100\end{array}$ & Nucleic acid & $2.01 \pm 0.09$ & $1.86 \pm 0.12$ & $1.89 \pm 0.18$ & $2.15 \pm 0.21$ & $2.30 \pm 0.22$ & $2.41 \pm 0.26$ \\
\hline $\begin{array}{l}\text { S/D treatment with buffer }(30 \mathrm{Vc}): 0.35 \% \mathrm{TnBP} .1 .0 \% \text { Triton } \\
\mathrm{X}-100.45^{\circ} \mathrm{C}\end{array}$ & Nucleic acid & $7.62 \pm 0.50$ & $7.88 \pm 0.53$ & $7.72 \pm 0.41$ & $7.54 \pm 0.62$ & $7.21 \pm 0.54$ & $7.36 \pm 0.62$ \\
\hline $\begin{array}{l}\text { System } \mathrm{T}^{\circ} \& \mathrm{~S} / \mathrm{D} \text { dropping gradient }(10 \mathrm{Vc}) \text { to start conditions } \\
\& \text { washing by } 10 \mathrm{Vc} \text { buffer }\end{array}$ & Nucleic acid & bsl & bsl & bsl & bsl & 0 & 0 \\
\hline \multirow{2}{*}{ Target FVIII/vWF complex elution } & Titer & bsl & bsl & 0 & 0 & 0 & 0 \\
\hline & Nucleic acid & bsl & bsl & 0 & 0 & 0 & 0 \\
\hline Whole process summed FVD & Nucleic acid & $9.63 \pm 0.48$ & $9.77 \pm 0.69$ & $9.61 \pm 0.45$ & $9.69 \pm 0.67$ & $9.51 \pm 0.58$ & $9.77 \pm 0.76$ \\
\hline
\end{tabular}

Table 1: Direct virus inactivation by S/D treatment during FVIII/vWF chromatographic purification process: Depending from temperature of S/D buffer; virus titer and nucleic acid content functional assessment; *bsl-value was below the method's sensitivity level. The gray line is excluded from kinetic calculations. 
Citation: Havryliuk SP, Krasnobryzha IM, Havryliuk OS, Volkov GL (2017) The Simultaneous Human FVIII/vWF Purification and Virus Inactivation Combined in Chromatographic Column. J Biomol Res Ther 6: 157. doi:10.4172/2167-7956.1000157

Page 6 of 9

Alternatively, the FVIII/vWF infection level was measured by virus titer. According to the titer, LEV infection in target protein preparation has intensively decreased to trace amount in parallel with nucleic acid quantity, but nearly twice as fast. For example, difference between RTPCR and titer methods for BVDV was 1.80 and 1.73 at $25(p<0.05)$ and $35^{\circ} \mathrm{C}(p<0.05)$, respectively; for PRV -2.07 and 1.83 at $25^{\circ} \mathrm{C}(p<0.05)$ and $35^{\circ} \mathrm{C}(p<0.05)$. On the other hand, the residual NLEVs virus titer determination in target proteins showed the same trends as for nucleic acid level, but lover $8-15 \%$ only. These data once again confirmed that the S/D destroyed LEVs and did not damage NLEVs, and the nucleic acids of both virus types were also not damaged. Destroyed viruses are not detected by titration, but RT-PCR method detecting nucleic acid determined both viruses, intact and destroyed.

In addition, a perceptible difference in the LEVs and NLEVs elimination from the column at the stage of growth gradient (MuLV/ CPV: $0.17 / 0.84 ; 0.68 / 1.01$ and $0.98 / 1.28$ at 25,35 and $45^{\circ} \mathrm{C}$ ) can be explained by the possible different surface charges of both type viruses and, as a result, by different interactions with the adsorbent. As demonstrated, in some cases, only empirical data can be relied upon to determine the appropriate virus surface charge because published isoelectric points of some capsid proteins may not be suitable for determining the total charge of the virus [41-43]. Nevertheless, in one of the chromatographic and other isoelectric points studies it was shown that some LEVs (MuLV, BVDV) displayed an overall net negative charge above $\mathrm{pH} 6$ and a positive net charge below $\mathrm{pH}$ 6 [41,42], whilst most NLEVs were positively charged at a $\mathrm{pH}$ below 7 and negatively charged at a $\mathrm{pH}$ above 7 [43]. It means that under inactivation buffer $\mathrm{pH} 7.2$ in our experiments LEVs will have a weak positive charge and will interact with strong negative charge of WorkBeads $40 \mathrm{~S}$ and their elution will braked by gel. Opposite, NLEVs will have neutral surface charge, will not interact with gel and will free flowed out from column.

It should be noted that the most typical kinetic of virus inactivation process were observed at $35^{\circ} \mathrm{C}$ for both LEVs and NLEVs, so the experimental conditions of this stage were used in next investigations with incremental changes in the volume of inactivation buffer, S/D additives and their concentration and chromatographic adsorbent.
Dependence from treatment time: Results of the S/D virus inactivation of FVIII/vWF directly in a chromatographic column depending from process time as a function of the volume of inactivation buffer are presented in Tables 1 and 2. The time of S/D treatment played important role in virus elimination same as a temperature: total levels of LEVs decreasing according to PCR-detected virus nucleic acid (calculated from mass-balance) after 60,70 and 80 min treatment at $35^{\circ} \mathrm{C}\left(30,35\right.$ and $40 \mathrm{Vc}$ at flow rate $\left.0.5 \mathrm{Vc} \times \mathrm{h}^{-1}\right)$ were 89.4-92.6, 96.199.0 and $100 \%$ respectively. Differences were statistically significant for all LEVs ( $p<0.001$ in all cases). According to the virus titer, infection in target protein has intensively decreased to trace amount in parallel with nucleic acid quantity, but was 1.8-2.0 time effective and statistically significant for all LEVs and time of treatment. For NLEVs the treatment during 60, 70 and $80 \mathrm{~min}$ was enough sufficient and effective: total elimination was $94.1 \%, 98.4$ and $100 \%$, respectively. The residual virus titer determination in target proteins showed the same trends as for nucleic acid level.

Dependence from S/D additives: Results of the S/D virus inactivation of FVIII/vWF directly in a chromatographic column depending from used S/D additives are presented in Tables 1 and 3 . It was found that the solvent structure/properties have a certain effect on the elimination both LEVs and NLEVs. The main parameter-target protein complex infection-after LEVs treatment at $35^{\circ} \mathrm{C}$ was $2.0-2.5$ time higher calculated by titration method and 1.4-1.9 time by RTPCR method when TnBP solvent was replaced by DnPP at the same concentration $1.0 \%$ (all differences were statistically significant, for BVDV: $p_{\text {titter }}<0.05, p_{\mathrm{NA}}<0.01$; for MuLV: $\left.p_{\text {titter }}<0.01, p_{\mathrm{NA}}<0.01\right)$. The drop NA/titre ratio from 2.13 to 1.55 indicated that the level of virus destruction in the whole elimination process decreased after solvent changing, which leads to elution more intact LEVs from the column. The kinetics of NLEVs washing out was a little bit slowed down after TnBP replacement by DnPP, which led to a statistically significant decrease in the level of virus elimination by a factor 2.6-3.8 (for CPV: $p_{\text {titter }}<0.01, p_{\mathrm{NA}}<0.001$; for BEV: $\left.p_{\text {titter }}<0.01, p_{\mathrm{NA}}<0.001\right)$.

Moreover, the known scientific articles did not support us by any date of DnPP affecting the inactivation process. It is known only that DnPP was used as a solvent for LEVs inactivation [10,44,45]. Results of

\begin{tabular}{|c|c|c|c|c|c|c|c|}
\hline \multirow{2}{*}{ S/D treatment stage } & \multirow{2}{*}{$\begin{array}{c}\text { Virus } \\
\text { determination }\end{array}$} & \multicolumn{6}{|c|}{ Decreasing the factor of virus concentration (FVD) as a $\log _{10}(M \pm S E M ; n=5)$} \\
\hline & & BVDV & DHBV & MuLV & PRV & CPV & BEV \\
\hline $\begin{array}{l}\text { System growth gradients: } \mathrm{T}^{\circ} 18-35^{\circ} \mathrm{C} .10 \mathrm{Vc} \text { S/D } \\
0-0.35 \% \text { TnBP, } 0-1.0 \% \text { Triton } \mathrm{X}-100\end{array}$ & Nucleic acid & $1.19 \pm 0.10$ & $1.27 \pm 0.16$ & $1.30 \pm 0.12$ & $1.24 \pm 0.11$ & $1.71 \pm 0.14$ & $1.60 \pm 0.11$ \\
\hline $\begin{array}{l}\text { S/D treatment with buffer }(35 \mathrm{Vc}): 0.35 \% \text { TnBP. } 1.0 \% \\
\text { Triton } \mathrm{X}-100,35^{\circ} \mathrm{C}\end{array}$ & Nucleic acid & $7.79 \pm 0.43$ & $7.61 \pm 0.62$ & $7.85 \pm 0.58$ & $8.01 \pm 0.70$ & $6.21 \pm 0.49$ & $6.09 \pm 0.56$ \\
\hline $\begin{array}{l}\text { System } \mathrm{T}^{\circ} \& \mathrm{~S} / \mathrm{D} \text { dropping gradient }(10 \mathrm{Vc}) \text { to start } \\
\text { conditions and washing by } 10 \mathrm{Vc} \text { buffer }\end{array}$ & Nucleic acid & $0.36 \pm 0.03$ & $0.30 \pm 0.02$ & $0.39 \pm 0.03$ & $0.26 \pm 0.02$ & $1.60 \pm 0.12$ & $1.81 \pm 0.15$ \\
\hline \multirow{2}{*}{ Target FVIII/vWF complex elution } & Titer & $0.18 \pm 0.05$ & $0.20 \pm 0.06$ & $0.11 \pm 0.03$ & bsl & $0.15 \pm 0.04$ & $0.10 \pm 0.02$ \\
\hline & Nucleic acid & $0.29 \pm 0.03$ & $0.37 \pm 0.03$ & $0.18 \pm 0.02$ & $0.10 \pm 0.01$ & $0.19 \pm 0.02$ & $0.12 \pm 0.01$ \\
\hline Whole process summed FVD & Nucleic acid & $9.63 \pm 0.44$ & $9.55 \pm 0.67$ & $9.72 \pm 0.59$ & $9.61 \pm 0.77$ & $9.71 \pm 0.52$ & $9.62 \pm 0.59$ \\
\hline $\begin{array}{l}\text { System growth gradients: } \mathrm{T}^{\circ} 18-35^{\circ} \mathrm{C} .10 \mathrm{Vc} \text { S/D } \\
0-0.35 \% \text { TnBP, } 0-1.0 \% \text { Triton X-100 }\end{array}$ & Nucleic acid & $1.16 \pm 0.13$ & $1.24 \pm 0.11$ & $1.38 \pm 0.15$ & $1.32 \pm 0.08$ & $1.83 \pm 0.16$ & $1.65 \pm 0.10$ \\
\hline $\begin{array}{l}\text { S/D treatment with buffer }(40 \mathrm{Vc}): 0.35 \% \text { TnBP. } 1.0 \% \\
\text { Triton } \mathrm{X}-100,35^{\circ} \mathrm{C}\end{array}$ & Nucleic acid & $8.47 \pm 0.64$ & $8.51 \pm 0.68$ & $8.23 \pm 0.57$ & $8.40 \pm 0.73$ & $7.91 \pm 0.62$ & $8.02 \pm 0.73$ \\
\hline $\begin{array}{l}\text { System } \mathrm{T}^{\circ} \& \text { S/D dropping gradient }(10 \mathrm{Vc}) \text { to start } \\
\text { conditions \& washing by } 10 \mathrm{Vc} \text { buffer }\end{array}$ & Nucleic acid & bsl & bsl & bsl & bsl & 0 & 0 \\
\hline \multirow{2}{*}{ Target FVIII/vWF complex elution } & Titer & 0 & 0 & 0 & 0 & 0 & 0 \\
\hline & Nucleic acid & 0 & 0 & 0 & bsl & 0 & 0 \\
\hline Whole process summed FVD & Nucleic acid & $9.63 \pm 0.65$ & $9.75 \pm 0.81$ & $9.61 \pm 0.59$ & $9.72 \pm 0.77$ & $9.74 \pm 0.64$ & $9.67 \pm 0.74$ \\
\hline
\end{tabular}

Table 2: Direct virus inactivation by S/D treatment during FVIII/vWF chromatographic purification process: Depending from volume of S/D buffer; virus titer and nucleic acid content functional assessment; *bsl-value was below the method's sensitivity level. The gray line is excluded from kinetic calculations. 
Citation: Havryliuk SP, Krasnobryzha IM, Havryliuk OS, Volkov GL (2017) The Simultaneous Human FVIII/vWF Purification and Virus Inactivation Combined in Chromatographic Column. J Biomol Res Ther 6: 157. doi:10.4172/2167-7956.1000157

Page 7 of 9

this study are rather poor to draw any conclusions about the mechanism of DnPP regulation of the virus inactivation process.

Both detergents Triton X-100 and Tween 80 are the basic in S/D treatment the proteins for virus inactivation. More than 2500 review articles stated that the most frequently used combination of S/D are $0.35-1.0 \%$ TnBP and $1 \%$ Triton X-100 or Tween 80 [10]. In that references shown that all possible enveloped viruses were completely killed by that combination of $\mathrm{R} / \mathrm{D}$ at $4-30^{\circ} \mathrm{C}$ for a few seconds, minutes or hours. The vaccinia virus was found to be relatively resistant to inactivation by these $\mathrm{R} / \mathrm{D}$ additives. Treatment with $\mathrm{TnBP} /$ Triton X-100 rapidly inactivated several viruses by 34.0-5.0 $\log _{10}$ within 15 seconds. Virus inactivation with $\mathrm{TnBP} /$ Tween 80 was slower, but effective inactivation same viruses (4.0-6.3 $\log 10)$ within $30 \mathrm{~min}$. To achieve $4.0 \log _{10}$ reduction of vaccines required an incubation time of 10 min with TnBP/Triton X-100 and 6-24 hrs with TnBP/Tween $80[10,46]$. The obvious difference is the action of two main viruses inactivation detergents the explanations have not been received yet.

Unfortunately, we also cannot unambiguously explain the results of the less successful virus inactivation by $\mathrm{R} / \mathrm{D}$ combination of TnBP/ Tween 80 compared with TnBP/Triton X-100 (Table 3). So far, the only speculation is the following: the larger molecule Tween 80 more slowly reaches the lipid bilayer of the viral membrane, and this causes the lower rate of inactivation process.
Target protein yield and activity after in-column treatment: The standard yield of FVIII/vWF on the stage of cation exchange chromatography with WorkBeads $40 \mathrm{~S}$ is $75.9 \pm 3.6 \%$ with specific activity $13.3 \pm 0.2 \mathrm{IU} / \mathrm{mg}$ complex determined by FVIII:C. Results shown in Table 4 suggested that proteins "nailed" to chromatographic gel and added to virus S/D treatment was eluted from chromatographic in the native state. This is evidenced by the standard for WorkBeads $40 \mathrm{~S}$ yield of proteins complex $(75.4 \pm 5.2$ for S/D treatment, $p>0.5)$ and its specific activity (13.4 $\pm 0.3 \mathrm{IU} / \mathrm{mg}$ complex for S/D treatment, $p>0.2$ ). Moreover, both the specific activity of FVIII:C at the stage of cation exchange chromatography and the yield of protein at a single chromatographic stage are quite typical for the purification process of coagulation FVIII/vWF complex [47,48].

No solvents and detergents were detected in target protein preparations.

\section{Conclusion}

Presented method of combined purification and virus elimination of FVIII/vWF complex directly in chromatographic column allowed to obtain the factor of virus concentration decrease values that were higher than those provided by known technologies and was sufficient to fully inactivate viruses. The method is recommended to use in pharmaceutical industry.

\begin{tabular}{|c|c|c|c|c|c|}
\hline \multirow[t]{2}{*}{ S/D treatment stage } & \multirow{2}{*}{$\begin{array}{l}\text { Virus } \\
\text { determination }\end{array}$} & \multicolumn{4}{|c|}{$\begin{array}{l}\text { Decreasing the factor of virus concentration (FVD) as a } \log _{10} \\
\qquad(M \pm S E M ; n=5)\end{array}$} \\
\hline & & BVDV & MuLV & CPV & BEV \\
\hline $\begin{array}{l}\text { System growth gradients: } \mathrm{T}^{\circ} 18-35^{\circ} \mathrm{C} .10 \mathrm{Vc} \text { S/D } \\
0-0.35 \% \text { DnPP, } 0-1.0 \% \text { Triton } \mathrm{X}-100\end{array}$ & Nucleic acid & $1.19 \pm 0.08$ & $1.05 \pm 0.11$ & $1.57 \pm 0.13$ & $1.43 \pm 0.10$ \\
\hline S/D treatment with buffer $(30 \mathrm{Vc}): 0.35 \%$ DnPP. $1.0 \%$ Triton $\mathrm{X}-100,35^{\circ} \mathrm{C}$ & Nucleic acid & $6.81 \pm 0.57$ & $6.63 \pm 0.65$ & $5.08 \pm 0.39$ & $5.19 \pm 0.46$ \\
\hline $\begin{array}{l}\text { System } \mathrm{T}^{\circ} \& \mathrm{~S} / \mathrm{D} \text { dropping gradient }(10 \mathrm{Vc}) \text { to start conditions and washing by } 10 \\
\text { Vc buffer }\end{array}$ & Nucleic acid & $0.54 \pm 0.06$ & $0.62 \pm 0.04$ & $1.48 \pm 0.09$ & $1.31 \pm 0.11$ \\
\hline \multirow{2}{*}{ Target FVIII/vWF complex elution } & Titer & $0.79 \pm 0.13$ & $0.84 \pm 0.10$ & $1.63 \pm 0.28$ & $1.57 \pm 0.33$ \\
\hline & Nucleic acid & $1.18 \pm 0.10$ & $1.35 \pm 0.12$ & $1.54 \pm 0.14$ & $1.69 \pm 0.11$ \\
\hline Whole process summed FVD & Nucleic acid & $9.72 \pm 0.58$ & $9.65 \pm 0.67$ & $9.67 \pm 0.44$ & $9.62 \pm 0.50$ \\
\hline $\begin{array}{l}\text { System growth gradients: } \mathrm{T}^{\circ} 18-35^{\circ} \mathrm{C} .10 \mathrm{Vc} \text { S/D } \\
0-0.35 \% \text { TnBP, } 0-1.0 \% \text { Tween } 80\end{array}$ & Nucleic acid & $1.63 \pm 0.09$ & $1.75 \pm 0.07$ & $1.61 \pm 0.15$ & $1.53 \pm 0.12$ \\
\hline $\mathrm{S} / \mathrm{D}$ treatment with buffer $(30 \mathrm{Vc}): 0.35 \% \mathrm{TnBP}, 1.0 \%$ Tween $80.35^{\circ} \mathrm{C}$ & Nucleic acid & $5.19 \pm 0.47$ & $5.41 \pm 0.53$ & $5.59 \pm 0.61$ & $5.80 \pm 0.81$ \\
\hline $\begin{array}{l}\text { System } \mathrm{T}^{\circ} \& \mathrm{~S} / \mathrm{D} \text { dropping gradient }(10 \mathrm{Vc}) \text { to start conditions and washing by } 10 \\
\text { Vc buffer }\end{array}$ & Nucleic acid & $0.32 \pm 0.02$ & $0.24 \pm 0.02$ & $1.52 \pm 0.07$ & $1.48 \pm 0.09$ \\
\hline \multirow{2}{*}{ Target FVIII/vWF complex elution } & Titer & $1.95 \pm 0.11$ & $1.77 \pm 0.13$ & $0.90 \pm 0.16$ & $0.75 \pm 0.10$ \\
\hline & Nucleic acid & $2.49 \pm 0.19$ & $2.36 \pm 0.22$ & $0.97 \pm 0.04$ & $0.81 \pm 0.04$ \\
\hline Whole process summed FVD & Nucleic acid & $9.63 \pm 0.52$ & $9.76 \pm 0.58$ & $9.69 \pm 0.63$ & $9.62 \pm 0.83$ \\
\hline
\end{tabular}

Table 3: Direct virus inactivation by S/D treatment during IgG chromatographic purification process: depending from type of S/D additives; virus titer-nucleic acid content and protein quantity functional assessment; *bsl-value was below the method's sensitivity level. The gray line is excluded from kinetic calculations.

\begin{tabular}{|c|c|c|c|c|c|c|c|c|c|}
\hline \multicolumn{6}{|c|}{$\begin{array}{l}\text { Basic conditions of chromatography and } \\
\text { S/D treatment }\end{array}$} & \multicolumn{4}{|c|}{ FVIII/vWF yield after S/D treated $M \pm S E M ; n=5$} \\
\hline $\mathbf{T}^{\circ} \mathbf{C}$ & $\begin{array}{c}{ }^{*} t \\
\min \end{array}$ & $\underset{\%}{\operatorname{TnBP}}$ & $\underset{\%}{\operatorname{DnPP}}$ & $\begin{array}{c}\text { Triton X-100 } \\
\%\end{array}$ & $\begin{array}{c}\text { Tween } 80 \\
\%\end{array}$ & $\begin{array}{l}\text { Protein } \\
\text { mg }\end{array}$ & $\%$ & $\begin{array}{c}\text { FVIII:C } \\
\text { activity } \\
\text { IU }\end{array}$ & $\%$ \\
\hline 25 & 60 & 0.35 & - & 1.0 & - & $18.5 \pm 1.1$ & 74.9 & $256.2 \pm 16.8$ & 77.5 \\
\hline \multirow{5}{*}{35} & \multirow{3}{*}{60} & 0.35 & - & 1.0 & - & $19.0 \pm 0.8$ & 77.1 & $243.7 \pm 20.1$ & 73.7 \\
\hline & & 0.35 & - & - & 1.0 & $18.9 \pm 1.3$ & 76.4 & $248.6 \pm 18.8$ & 75.2 \\
\hline & & - & 0.35 & 1.0 & - & $18.4 \pm 0.9$ & 74.5 & $247.6 \pm 21.4$ & 74.9 \\
\hline & 70 & 0.35 & - & 1.0 & - & $18.3 \pm 1.2$ & 74.1 & $248.3 \pm 15.9$ & 75.1 \\
\hline & 80 & 0.35 & - & 1.0 & - & $18.7 \pm 1.5$ & 75.8 & $253.5 \pm .14 .2$ & 76.7 \\
\hline 45 & 60 & 0.35 & - & 1.0 & - & $18.9 \pm 1.2$ & 76.4 & $249.3 \pm 17.5$ & 75.4 \\
\hline $55 \dagger$ & - & - & - & - & - & $18.2 \pm 2.0$ & 73.8 & $246.6 \pm 19.6$ & 74.6 \\
\hline
\end{tabular}

Table 4: Target FVIII/VWF complex activity assessment in preparations that were on-column treated by solvent/detergent (24.7 $\pm 1.3 \mathrm{mg}$ of human FVIII/vWF complex with total activity FVIII: C $330.7 \pm 12.4 \mathrm{IU}$ were applied into the columns). ${ }^{*}$-the time of actual treatment stage; $55 \dagger-$ the temperature of critical zone determination for WorkBeads 40S 
Citation: Havryliuk SP, Krasnobryzha IM, Havryliuk OS, Volkov GL (2017) The Simultaneous Human FVIII/vWF Purification and Virus Inactivation Combined in Chromatographic Column. J Biomol Res Ther 6: 157. doi:10.4172/2167-7956.1000157

\section{Acknowledgements}

Authors express profound gratitude to the staff of pilot plant of scientific and manufacturing firm Shijir International Co. Ltd, Sukhbaatar sq., Bodi Tower building, Ulaanbaatar, Mongolia, for the opportunity to intervene in the real manufacturing processes and to test the represented method on the pilot plant in the Raining (Boroo) Valley of Mongolia.

\section{References}

1. Felgenhauer M, Mison D, Montandon F, Farcet M (2016) Using a modified solvent-detergent viral inactivation method Patent US No. CN 103370072 B.

2. Roberts PL, Lloyd D, Marshall PJ (2009) Virus inactivation in a factor VIII/VWF concentrate treated using a solvent/detergent procedure based on polysorbate.

3. Roberts PL (2008) Virus inactivation by solvent/detergent treatment using Triton X-100 in a high purity factor VIII. Biologicals 36: 330-335.

4. Biesert L, Suhartono H, Klengel R, Schmidt T, Radomski KU (2006) Vira safety of a novel von willebrand factor and factor VIII concentrate (Wilate ${ }^{\circledR}$ ): virus inactivation capacities of optimised Solvent/detergent and terminal dryheat treatment (PermaHeat).

5. Goudemand J, Scharrer I, Berntorp E, Lee CA, Borel-Derlon A, et al. (2005) Pharmacokinetic studies on Wilfactin ${ }^{\circledR}$, a von Willebrand factor concentrate with a low factor VIII content treated with three virus-inactivation/removal methods. J Thromb Haemost 3: 2219-27.

6. Burnouf T, Goubran HA, Radosevich M, Sayed MA, Gorgy G, et al. (2006) A minipool process for solvent-detergent treatment of cryoprecipitate at blood centres using a disposable bag system. Vox Sanguinis 91: 56-62.

7. Sofer G (2003) Virus inactivation in the 1990s-and into the 21st century. Biopharm Int 16: 50-57.

8. Scott C (2000) Special report: a world of difference-biosimilars and biobetters offer unique benefits-and risks.

9. Chen L, Yao M (2001) Pathogen inactivation plays an irreplaceable role in safeguarding the safety of blood transfusion. J Antivir Antiretrovir.

10. Sofer G (2003) Virus inactivation in the 1990s- and into the 21st century Part 3a, Plasma and plasma products (heat and solvent/detergent treatments). BioPharm Int 15: 28-42.

11. Hellstern P, Solheim BG (2011) The use of solvent/detergent treatment in pathogen reduction of plasma. Transfus Med Hemother 38: 65-70.

12. Schmidt T, Kuehnel D, Mueller S, Pichotta A, Radomski KU, et al. (2016) Inactivation of Zika virus by solvent/detergent treatment or pasteurization. Blood 128: 2630.

13. Kim IS, Choi YW, Kang Y, Sung HM, Shin JS (2008) Dry-heat treatment process for enhancing viral safety of an antihemophilic factor VIII concentrate prepared from human plasma. J Microbiol Biotechnol 18: 997-1003.

14. Dichtelmüller HO, Germer M, Rudnick DC (2005) A general approach to robustness studies for virus inactivating and partitioning steps used in production of plasma derivatives. Bioprocess Int 3: 35-38.

15. Shukla AA, Aranha H (2015) Viral clearance for biopharmaceutical downstream processes. Pharm. Bioprocess 3: 127-138.

16. Casademunt E, Martinelle K, Jernberg M, Winge S, Tiemeyer M, et al. (2012) The first recombinant human coagulation factor VIII of human origin: human cell line and manufacturing characteristics. Eur J Haematol 89: 165-176.

17. Remington KM (2015) Fundamental strategies for viral clearance-Part 2: Technical approaches. Bioprocess Int 13: 10-16.

18. Pisal DS, Kosloski MP, Balu-lyer SV (2010) Delivery of therapeutic proteins. J Pharm Sci 99: 2557-2575.

19. Gholikandi GB, Dehghanifard E, Sepehr MN, Torabian A, Moalej S, et al. (2012) Performance evaluation of different filter media in turbidity removal from water by application of modified qualitative indices. Iran J Public Health 41: 87-93.

20. Volkov GL, Havryliuk SP, Krasnobryzha IM, Havryliuk OS (2017) The protein peptide direct virus inactivation during chromatographic process: development approaches. Appl Biochem Biotechnol 181: 233-249.

21. Kim IS, Bae JE, Sung HM, Kang Y, Choi YW (2009) Removal and inactivation of viruses during the manufacture of a high-purity antihemophilic factor IX from human plasma. Biotechnol. Bioprocess Eng 14: 716-724.
22. Volkov GL, Gavrylyuk SP, Krasnobryzha IM, Zhukova AI, Gavryliuk OS (2016) Method for isolation complex of Factor VIII and von Willebrand Factor from blood plasma using gel-exclusion column chromatography. Ukrainian Patent 110920

23. Bradford MM (1976) A rapid and sensitive for the quantitation of microgram quantities of protein utilizing the principle of protein-dye binding. Anal Biochem 72: $248-254$.

24. Stoscheck CM (1990) Quantitation of protein. Methods Enzymol 182: 50-68.

25. Kaerber G (1931) Beitrag zur kollektiven Behandlung pharmakologischer Reihenversuche. Naunyn Schmiedbergs Arch Exp Pathol Pharmakol 162: 480-483.

26. Spearman C (1908) The method of "right and wrong cases" ("constant stimuli") without Gauss's formulae. Br J Psyhol 2: 277-282.

27. Uruno K, Shibata I, Nakane T (1998) Detection of bovine viral diarrhea virus (BVDV) using reverse transcription polymerase chain reaction assay. J Vet Med Sci 60: 867-870.

28. Ley V, Higgins J, Fayer R (2002) Bovine enteroviruses as indicators of fecal contamination. Appl Environ Microbiol 68: 3455-3461.

29. Zubkova NV, Anastasiev VV, Kyuregyan KK, Mikhailov MI, Lobastova AK, et al. (2013) Estimation of efficiency of solvent-detergent method for virus inactivation in the technology of immunoglobulin production on the model of Duck Hepatitis B virus. Byulleten' Eksperimental'noi Biologii i Meditsiny 155: 788-792.

30. Wang Y, Li Y, Yang C, Hui L, Han Q, et al. (2013) Development and application of a universal Taqman real-time PCR for quantitation of duck hepatitis B virus DNA. J Virol Methods 191: 41-47.

31. Sharma P, Rastogi A, Kukreti K, Narwal PS (2012) Sensitivity assay of polymerase chain reaction for detection of canine Parvo virus infection in dogs J Clin Diagn Res 2: 45-47.

32. Kapil S, Cooper E, Lamm C, Murray D, Rezabek G, et al. (2007) Canine parvovirus type 2c and 2b circulating in North American dogs in 2006 and 2007. $\mathrm{J}$ Clin Microbiol 45: 4044-4047.

33. Tombacz D, Csabai Z, Olah P, Havelda Z, Sharon D, et al. (2015) Characterization of novel transcripts in pseudorabies virus. Virus 7: 2727-2744.

34. Lin Z, Puetter A, Coco J, Xu G, Strong MJ, et al. (2012) Detection of murine leukemia virus in the Epstein-Barr virus-positive human B-cell line JY, using a computational RNA-seq-based exogenous agent detection pipeline, PARSES. J Virol 86: 2970-2977.

35. Nellaiappan K, Nicklas G, Yao S, Malliaros DP (2001) Validation of a simple and sensitive gas chromatographic method for the analysis of tri-n-butyl phosphate from virally inactivated human immunoglobulin. J Cromatogr B 757: 181-189.

36. Strancar A, Raspor P, Schwinn H, Schutz R, Josic D (1994) Application of convective interaction media (CIM) supports for on-column solid phase Extraction of Triton X-100 and its determination in virus-inactivated human plasma by the solvent-detergent method. J Chromatogr A 658: 475-481.

37. Gavara PR, Bibi NS, Sanchez ML, Grasselli M, Fernandez-Lahore M (2015) Chromatographic characterization and process performance of column-packed anion exchange fibrous adsorbents for high throughput and high capacity bioseparations. Processes 3: 204-221.

38. Vasilenko OA (2011) Mathematical and statistical methods of analysis for applied research: a training manual. Popov Odesa' National Academy of Communication. Odessa, Ukraine.

39. Finkelschtein AV, Ptitsin OB (2000) Introduction to physic of the proteins: course of lectures. Mir, Moscow, Russia.

40. Volkov GL (2010) Increase in the yield of purified proteins in processes requiring virus inactivation. Proceedings of the 2nd International CongressPartnering Eurasia Bio., Moscow p: 343.

41. Herzer S, Beckett $P$, Wegman T, Moore P (2003) Isoelectric titration curves of viral particles as an evaluation tool for ion exchange chromatography. Life Science News, Amersham Biosciences.

42. Gao Y, Zhao X, Zang P, Liu Q, Wei G, et al. (2014) Generation of the bovine viral diarrhea virus E0 protein in transgenic Astragalus and its immunogenicity in Sika deer. Evidence-Based Complementary and Alternative Medicine p: 7.

43. Michen B, Graule T (2010) Isoelectric point of viruses. J Appl Microbiol 109 388-397. 
Citation: Havryliuk SP, Krasnobryzha IM, Havryliuk OS, Volkov GL (2017) The Simultaneous Human FVIII/vWF Purification and Virus Inactivation Combined in Chromatographic Column. J Biomol Res Ther 6: 157. doi:10.4172/2167-7956.1000157

Page 9 of 9

44. Neurath AR, Horowitz B (1989) Undenatured virus-free trialkyl phosphate treated biologically active protein derivatives. Patent US 4820805.

45. Neslund GG, Lin SL, Griffith MJ (1995) Ultrapurification process for Factor VIII. Patent US 5470954

46. Roberts PL (2000) Resistance of vaccinia virus to inactivation by solvent/ detergent treatment of blood products. Biologicals 28: 29-32.
47. Barington KA, Kaersgaard P (1999) A very-high-purity von Willebrand factor preparation containing high-molecular-weight multimers. Vox Sang 76: 85-89.

48. Knör S, Khrenov A, Laufer B, Benhida A, Grailly SC, et al. (2008) Efficient factor VIII affinity purification using a small synthetic ligand. J Thromb Haemost 6: $470-477$. 